\author{
Г. Ширинбаева ${ }^{1}$, Д. Азимбаева ${ }^{2}$, А. Иниятова ${ }^{3}$ \\ 1,2,3 Абай атындавы Қазақ ұлттық педагогикальққ университеті, \\ Алматы, Қазақ̧стан \\ ПЕДАГОГИКАЛЫҚ БІЛІМ БЕРУ КОНТЕКСІНДЕ ІЗГІЛІКТІ ОРТАНЫ
ҰЙЫМДАСТЫРУ ДЫН АКСИОЛОГИЯЛЫҚ АСПЕКТІЛЕРІ
}

\begin{abstract}
Ан̧датпа
Мақалада жоғарғы педагогикалық білім беруді гуманитарландыру және ізгілендіру тұжырымдамасының негіздемесі қарастырылды. Ізгілік ортаны ұйымдастырудың ғылыми құралы ретінде акцент әдіснама маңыздылығының аксиологиялық аспектісіне берілді.

Тұлға мен қоғамның қажеттіліктерін ашатын, білім беруді ізгілендіруді білім беру қызметі ретінде түсінуге ерекше назар аударылды. Жалпыадамзаттық құндылықтарды ақылмен интеграциялау, білім беруде алға қойылған мақсаттарға жету шарттарын бекітеді. Болашақ педагогтардың құндылықты бағдарларын қалыптастыру үдерісінде оқу-тәрбие жұмысын және жалпыадамзаттық құндылықтар практикасын интеграциялау мүмкіндіктеріне ерекше назар аударылады. Білім беру үдерісінің субьектісі ретінде тұлғаны қалыптастыруда "құндылық", “аксиология", “ізгілік” ұғымдарының жетекші рөлі анықталды. Мақалада педагогтарды кәсіби даярлаудың аксиологиялық тәсілінің мәні ашылған, әдіснамалық-теориялық және руханиадамгершілік деңгейлері қарастырылған.

Берілген деңгейлер тұрғысынан аксиологиялық тәсіл ізгілікті ортаны ұйымдастыру қағидасы және педагогикалық білім беру мазмұнын құру құралы ретінде қарастыруға болатыны негізделген. Педагогикалық білім беру контекстінде ізгілікті ортаны ұйымдастыру және болашақ педагогтардың санасын дамытудың аксиологиялық аспектілері баяндалады.
\end{abstract}

Түйін сөздер: педагогикалық білім беру, аксиология, құндылық, құндылықты бағдар, құндылқтар жіктемесі, ізгілік, жалпыадамзаттық құндылықтар, білім беру ортасы, метапән, үйлесімді, идеал, білім беру аспектілері, құндылықты бағдар, ықпалдастыру

\author{
G. Shirinbayeva ${ }^{1}$, D. Azimbaeva ${ }^{2}$, A. Iniyatova ${ }^{3}$ \\ ${ }^{1,2,3}$ Abay Kazakh national pedagogical university \\ Almati, Kazakhstan
}

\title{
AXIOLOGICAL ASPECTS OF THE ORGANIZATION OF THE HUMANISTIC ENVIRONMENTS IN THE CONTEXT OF PEDAGOGICAL EDUCATION
}

\section{Abstract}

The article discusses the axiological basis of the concept of humanization and humanization of higher pedagogical education.

The emphasis is on the axiological aspect of the importance of methodology as a scientific ways of organizing a humanistic environment.

Particular attention is paid to understanding the humanization of education as educational services that reflect the needs of the individual and society.

It is argued that the rational integration of universal values is a condition for achieving the goals set for education. Special attention is paid the possibilities of integrating educational work and practice of universal values in the process of forming value orientations for future teachers.

The concepts of "value", "axiology", "humanism" and their leading role in the formation of the personality of the subject of the educational process.

The article reveals the essence of the axiological approach in vocational training teachers, its levels are considered: theoretical and methodological and moral and spiritual.

It is proved that from the perspective of these levels, the axiological approach canconsidered as a principle of organization of the humanistic environment and a way of building the content of teacher education. 
Setting out axiological aspects in organizations of the humanistic environment and development of consciousness of future teachers in the context of teacher education.

Key word: teacher education, axiology, values, value systems, value classification, humanism, universal values, educational environment, meta subject, harmony, ideal, aspects of education, value orientation, integration

\author{
Г. Ширинбаева ${ }^{1}$, Д. Азимбаева ${ }^{2}$, А. Иниятова ${ }^{3}$ \\ 1,2,3 Абай атындавы Қазақ ұлттық педагогикальққ университеті, \\ Алматы, Казахстан
}

\title{
АКСИОЛОГИЧЕСКИЕ АСПЕКТЫ ОРГАНИЗАЦИИ ГУМАНИСТИЧЕСКОЙ СРЕДЫ В КОНТЕКСТЕ ПЕДАГОГИЧЕСКОГО ОБРАЗОВАНИЯ
}

\author{
Аннотация \\ В статье рассмотрены аксиологические основания концепции гуманизации и \\ гуманитаризации высшего педагогического образования. \\ Акцент сделан на аксиологический аспект значимости методологии как научного способа \\ организации гуманистической среды.
}

Особое внимание обращается на понимание гуманитаризации образования как образовательной услуги, которая отражает потребности личности и общества.

Утверждается, что разумное интеграция общечеловеческих ценностей является условием достижения целей, поставленных перед образованием. Особое внимание уделяется возможностям интеграции учебно-воспитательной работы и практики общечеловеческих ценностей в процессе формирования ценностных ориентаций у будущих педагогов.

Представлены понятие “ценность”, “аксиология", “гуманизм” и их ведущая роль в формировании личности субъекта образовательного процесса.

B статье раскрыта сущность аксиологического подхода в профессиональной подготовке педагогов, рассмотрены его уровни: теоретико-методологический и нравственно-духовной. Обосновано, что с позиции данных уровней аксиологический подход может рассматриваться как принцип организащии гуманистической среды и способ построения содержания педагогического образования. Излагаются аксиологичекие аспекты в организаций гуманистической среды и развития сознания будуших педагогов в контексте педагогического образования.

Ключевые слова: педагогическое образование, аксиология, ценности, ценностные ориентации, классификация ценностей, гуманизм, общечеловеческие ценности, образовательная среда, метапредмет, гармония, идеал, аспекты образования, ценностный ориентация, интеграция

Кіріспе.Қазіргі заманауи педагогика үздіксіз дамитын ғылым саласы ретінде, оның көкейкесті зерттеулері, жалпы білім беру жүйесінің даму деңгейімен, оның құндылықты әлеуетімен тығыз байланысты. Сондықтан педагогикалық үдерісте, пәннің құрылымдық-мазмұндық маңыздылығын анықтайтын, құндылықты бағдарын күшейту міндеттерін дамыту өте маңызды және өзекті. Тәрбие мен оқытудағы ізгілікке бағытталған идеалдар құндылықтар болып саналады. Сол құндылықтар негізінде педагогикада білім берудің аксиологиялық аспектілері қарастырылады. Демек, оқутәрбиені жоспарлаған педагогикалық үдеріс, тұлғаны әлеуметтендіру, дамыту заңдылықтарына сәйкес, ең алдымен оның әдіснамасы мен аксиологиялық әлеуетін талдауды қажет етеді. Кезкелген педагогикалық үдерістің аксиологиялық әлеуеті, білім беру ортасын ізгілендіру шартарын құрайды.

Аксиология (грекше axios - құнды, $\log 0$ - - ілім) - “құндылық” категориясын зерттейтін философия саласы болып табылады. Құндылық категориясын зерттейтін ғылым саласының ғылыми айналымға енуі: Я.А.Коменский, И.Г.Песталоцци, К.Д.Ушинский, Я.Корчак, А.С.Макаренко, В.А.Сухомлинский А. Дистервег, С.И.Гессен, Я.Корчак, Ш.А.Амонашвили, Ә.А.Бейсенбаева және т.б. ғалымдардың еңбектерінен бастау алып, оған ғылыми-педагогогикалық негіз болған.

Сонымен қатар, XX ғасырдың соңы және XXI ғасырдың басындағы он жылда адамның рухани мәселесіне тұтастық, кемелденуге ұмтылу, біріңғай рухани-материалдық әлемі туралы ілім: М.Мамардашвили, А.Н.Нысанбаев, А.А.Радугина, А.Г.Косиченко, Г.Г.Соловьева, А.А.Хамидова және т.б. философ ғалымдардың еңбектерінде көрініс тапты. Ғалымдар, педагогика 
әдіснамасының пәнін және оның құндылықты мәнін кеңейтуді мақсат ете отырып, жалпы білім беру жүйесін жетілдіруді, жеке тұлғаның үйлесімді дамуын, қамтамасыз етуге байланысты негізгі әдіснамалық мәселелерді ашып көрсетеді. Ғалымдардың педагогикалық идеяларының мәні, білім беру ретінде танымдық (білім, білік) ғана емес, сонымен бірге Аксиологиялық "Мен" ішкі бағдарда маңызды рөл атқаратын тұлғаға бағытталған компоненттерді қамтуды назарға алады. Бұл білім беру ортасын жаңаша мазмұнда ізгілік ортада құруды, педагогика теориясы мен практикасының аксиологиялық әлеуетінің негізінде күшейтуді талап етеді. Себебі: тұлғаның Аксиологиялық “Мен” ішкі бағдарда кемелдену қызметін қамтамасыз ету үшін, білім беру, тәрбиелеу теориясы мен әдістемесінің жаңартылған мазмұны оқытудың жаңа құндылықты бағдарын күшейту бойынша ұлы мақсаттар қоюды өзектендіреді[1].

Педагогикада аксиологиялық тәсілді қолдану салдары болып табылатын білім берудің ізгілендіру идеясы, кең философиялық-антропологиялық бағытты, әлеуметтік-саяси мәнді иеленеді, өйткені, оның шешімімен адам мен өркениетті дамытатын, не оның дамуын тежейтін қоғамдық қозғалыстың стратегиясы тығыз байланысты.

Жалпы педагог кадрларды құндылықты бағдарда кәсіби даярлау, адам өмір сүруінің адамгершілік, жоғары мағыналары ретінде, бірінші дәрежелі маңызға ие. Бұл Е. В. Бондаревский, Б. С. Гершунский, Н. Д. Никандрова, 3. И. Равкина, Е. Н. Шиянова, А. И. Липский, В. А. Сластенин және т. б. еңбектерде қарастырылған зерттеулермен айқындалды. Философ, әлеуметтанушы, педагог, психолог ғалымдардың зерттеулерін талдау, құндылық категориясына маңызды, тиімді, пайдалы, тұтас мақсатты, заттық, бағалау, рухани, материалдық, қоғамдық, жеке, абстрактілі, моральдық, қажетті, нормативтік ретінде қарауға мүмкіндік береді. Күрделі және біртекті емес құндылықтар құрылымы болуы оның көптеген жіктемелерін анықтайды.

XXI ғасырда құндылықтар жүйесін, тек философия ғылымында ғана емес, әлеуметтікгуманитарлық ғылымдардың бәріне дерлік ортақ нысана, өзекті тақырыпқа айналды.

Философиялық тұжырымдамаларда құндылықтар абсолюттік және салыстырмалы (И. Кант, Н. О. Лосский), идеал және нақты (Н. Гартман), жеке және әлеуметтік (В. П. Тугаринов, Э. Дюркгейм), ішкі және сыртқы (Конфуций), объективті және субъективті (М. Вебер, М. Шелер) болып бөлінеді. Психологиялық теорияларда құндылықтарды оң және теріс деп ажыратады, нақты және абстрактілі (К. А. Абульханова-Славская), материалдық және рухани (Б. Г. Ананьев), терминалдық және аспаптық (У. Билски, Д. А. Леонтьев, М. Рокич, Ш. Шварц).

Сондай-ақ, идеал - құндылықтары, қасиет - құндылықтары, мінез-құлық - құндылықтары (С. С. Бубнова), заттық құндылықтар (О. Г. Дробиницкий), мәдениет және өмір құндылықтары (Г. П. Выжлецов); наным - құндылықтары, сапа - құндылықтары және сезім - құндылықтары (Л. К. Иванова) және т. б. бар. Білім беру философиясының ізгілікке бағдарлануы, білім берудің барлық сатыларында жүзеге асырылатын стратегиялық бағдарламаларды сапалы жаңартылу. Бұл маңызды ізгілікті орта құруға бағытталған бағдарламаларды әзірлеу, оқу-тәрбие үдерісінің ескі және жаңа білім беру тұжырымдамаларына, педагогикалық тәжірибелеріне, және оның қателіктері мен жетістіктеріне бағалау критерийлерін орнатуға мүмкіндік береді [2].

Ізгілендіру идеясы мүлдем өзгеше бағыттағы білім беруді жүзеге асыруды көздейді, ол болашақ «жұмыссыз» жас білікті кадрларды дайындаумен байланысты емес, керісінше жалпы нәтижелілікке қол жеткізе отырып, кәсіби дамыған жеке тұлғаны дайындауға ықпале етеді. Педагогикада аксиологиялық тәсілді қолдану салдары болып табылатын білім берудің ізгілендіру идеясы, кең философиялық-антропологиялық бағытты, әлеуметтік-саяси мәнді иеленеді, өйткені, оның шешімімен адам мен өркениетті дамытатын, не оның дамуын тежейтін қоғамдық қозғалыстың стратегиясы тығыз байланысты. М.А.Данилов, Б.П. Есипов, Выготский, Ж. Пиаже, И.Я. Лернер және т.б. педагог ғалымдар "Педагогикалық мақсаттармен байланысты, аксиологиялық тәсілді қолдану барысында білім беру мазмұны деңгейлік сипаттамаға ие”, - деген идеяны алға тарта отырып, адамның болмысқа деген эмоционалды-құндылық қатынастар мәнін, құндылықтар жүйесінде ашып көрсетеді. Атап айтсақ, М.А.Данилов ғылым негіздерін оқытуда білім алушының белсенділігін арттыруға байланысты осы мәселені зерттеуде, білім алушының өзбетінше жұмыс жасауы үшін алдымен танымдық міндеттер қояды.

Білім алушының өзбетінше таным, шығармашылық іс-әрекеттерді саналы игеруін Б.П. Есипов, “тәжірибеде алынған білімді сәтті қолдана білу - оқытуда саналылықтың көрініс беруінің жоғары деңгейі", - деген тұжырыммен байланыстырады. Ол туралы білімді саналы ұғыну мәселесімен айналысқан, Л.С.Выготский, Ж.Пиаже: “Ұғыну сананың актісі болып табылады, оның пәні - сананың іс-әрекеті”, - деп ұғынуды сана әрекетінің ерекше бағыты ретінде ашып көрсетеді [3]. 
Ғалымдар жасаған педагогикалық ақпарат көздеріне талдаулық шолу жасасақ, саналы меңгерілген білімнің рухани-адамгершілік және зияткерлік екі аспектісіне сәйкес білім беру ортасын ізгілендіруге байланысты, оқыту мен тәрбие берудің тиімді өлшемдері шығады. Себебі, тұлғаның қабілетін арттырудың қажетті дербестік, деңгейі, оның қоршаған ортаға құндылық қатынасын жалпы өзін-өзі тануын қалыптастырады.

Осы білім берудің ізгілікті ортасында педагогикалық зерттеулердің субъектісі ретінде, тұлға өзінің жеке өзекті қабілет деңгейлерін органикалық дамытумен бірге, сана арқылы зияттық және рухани болмысын тануға бағыттауы тиіс. Ол тұтас педагогикалық үдерісті, әрбір пәннің мазмұнына интеграциялаудың нақты логикасын үлгілеу барысында жүзеге асады. Мұнда, білім берудің құндылықты бағдары тұлғаның өз бетінше Әлем, адам, табиғи қоршаған ортамен қатынасы жайлы білімді тұтас қарастыратын ізгілікті ортада ұйымдастырылады.

Ол туралы отандық ғалым А.А. Бейсенбаева: "Интеграциялау арқылы білімді ізгілендіру ұлттық, әлемдік мәдениетке, ұлттық және жалпыадамзаттық құндылықтарға басымдық бере отырып, тұтас қарастыру”, - деген пікір айтады. Ғалымның педагогикалық идеясының құндылықты мәні интеграциялық үдерістерді жетекші доминантты тенденция ретінде қарастыруы. Ал тұлғаның интеллектуалды, мотивациялық, мінез-құлық сферасын олардың диалектикалық бірілігінде біртұтас үйлесімді дамыту [4].

"Орта" ұғымының педагогика ғылымында кең қолданылуына қарамастан, оның дәл және біржақты анықтамасы жоқтығына байланысты, “орта" ұғымы “қоршаған орта" ретінде түсіндіріледі. Ж.Ж.Руссоның педагогикалық көзқарастарында “Орта” теориясын тұлғаның өзін-өзі оңтайлы дамыту жағдайы ретінде қарастыруы ерекше орын алады. Арнайы құрылған ортада тұлға дайын білімді алмайды, ол өзіндік тәжірибе негізінде тірі табиғатқа бақылау жасау арқылы білімді өзі өндіріп шығаруды үйрену арқылы алады [5].

“Орта" термині педагогикада және психологияда алғаш рет 20-жылдары пайда болды. Бұл кезде, педагогикалық зерттеулердің нәтижесінде ғылыми ортада "орта педагогикасы” (С.Т.Щацкий), “баланың қоғамдық ортасы” (П.П.Блонский), “қоршаған орта” (А.С.Макаренко) ұғымдары жеткілікті деңгейде жиі қолданылды. Сонымен қатар, білім беру ортасы туралы теорияның мәні психологиялық контексте, Л.С.Выготский, П.Я.Гальперин, В.В.Давыдов, Л.В.Занков, А.Н.Леонтьев, Д.Б.Эльконин және т.б. еңбектерінде ашылып, көрініс тапты. Ғалымдардың пікірлері бойынша, білім беру ортасы - бұл белгілі бір дәрежедегі реттелген, дамыта оқыту жүзеге асырылатын білім беру кеңістігі. Баланың өзінің әрекет ету тәсілдерін үнемі бір әлеуметтік-заттық ортада жетілдіруге мүмкіндігі болған жағдайда, қабілетті болады. Бұл Я.А.Коменскийдің "Ұлы дидактика" еңбегінде білім беру ортасының кеңістіктік-заттық компонентін модельдеу және ұйымдастыру ретінде көрініс тапқан. Егер жұмыс рухани аксиологиялық аспектілерге бағытталып ұйымдастырылған болса, онда тұлғаның үйлесімді даму дәрежесінде оқу-тәрбие әлеуеуті құндылықты рухани күйде болады. Ол ізгілікті ортада жүзеге асады" [6].

Ізгілік - адамгершілік, адамға сүйіспеншілік идеясын, білдіретін көзқарастар жүйесі. Осыған сәйкес ізгілікті педагогика жаршысы Ш.А.Амонашвили: “біз балаларды қандай болса сол қалпында жақсы көретін, жаны мейірімді адам болуымыз керек". "Баланы түсіну - яғни оның позициясын құрметтеу”, - деген пікірмен, кез-келген баланы қандай болса сол қалпында қабылдау туралы тәрбиедегі өзекті мақсаттарды алға қояды. Сонымен қатар, Ш.А.Амонашвили "рухани ізгілік” ұғымын енгізудің маңыздылығына тоқталды: “Өз санамызға руханилықтың өлшемін қабылдап, соның негізінде ойлау өте маңызды. Материалистік философия ойлау негіздері ретінде үш өлшемді құптайды - уақыт, материя, кеңістік. Ұлғайған сана осы өлшемдердің алдына тағы бір өлшемді - руханилықты қояды, оның өзегі Жоғарғы Бастауға деген сенім болып табылады. Рухани өлшем педагогиканы даналықпен толықтырып, болашаққа бағыттайды. Педагогикадағы жаңа ұғым - бұл рухани ізгілік. Ол бүкіл білім беру жүйесіне енуі тиіс. Руханилық, ізгілік, сүйіспеншілік, мейірімділік, бейбітшілік, игілік ұғымдарының негізінде педагогикалық сананы өзгерту ғана білім берудегі кедергілерді - қоғамдағы рухсыздық пен өнегесіздікті жеңуге мүмкіндік береді" [7].

Оның идеясы бойынша білім беру ортасын ізгілендіруде, баланың жеке қасиеттерін ашу арқылы жаны мен жүрегін нұрландыру және санасын тазарту, құндылқтар туралы түсініктерін кеңейтуге жағдай жасау басты мақсат. Осы бағытта білім беруді ізгілендіру қағидасының бала бойында байқалмаған, жарыққа шықпаған ішкі әлеуетін ашуда кездесетін кедергілерді жоюға мүмкіндігі кең құндылықтар тәжірибесінің рөлі ашылады. 
Ш.А. Амонашвили білім беру ортасын ізгілендіру үшін, келесі педагогикалық талаптарды ұстану қажеттілігін атап көрсетеді:

Бірінші. Ізгілікті білім беру ортасында бала өзінің еркін таңдау жасау әрекетінің үнемі онымен ілесіп жүретінін педагог сезінуі қажет. Педагогикалық үдерісте, ойын - бұл шындықты тану әдісі. Ал педагогтың рөлі, шабыт беру арқылы баланы үздіксіз танымдық іс-әрекетке бағдарлау.

Екінші. Педагог пен бала арасындағы ізгілікті білім беру ортасы айқын бейнеленген дамушы үдерісті сипаттауы қажет. Ізгілікті білім беру ортасы тұлғаның ізгілікті-жеке рухани бастауына қарай құрылатын педагогикалық-психологиялық мәнге ие.

Yшінші. Ізгілікті білім беру ортасы тұлғаға өмірдің жарқын сәттерін сыйлайды. Себебі: бала ерекше рухани күш иесі. Демек, арнайы ұйымдастырылған ізгілікті білім беру ортасы, оның түгел танымдық, өмірлік, рухани қажеттіліктерін және өзін-өзі тану ұмтылысын қанағаттандыруы тиіс [8].

Педагогикалық білім беру үдерісінің аксиологиялық компонентінің ізгілікті бағыттылығы:

- Субьектілердің құндылықты бағдарының ізгілікті жүйесіне, жалпыадамзаттық құндылықтардың өзара әсер етуі;

- Салауатты өмір сүру тәжірибесінде жалпыадамзаттық құндылықтарды жүзеге асыру мақсатында, субьектінің үздіксіз әлеуметтік-мәдени тәжірибелерді ашу және жинақтау дайындығына жағдай жасау;

- Ар-ождан еркіндігін қамтамасыз ету, адамгершілік нормаларға қарама қарсы келмейтін, түрлі қоғамдық және саяси ұйымдардың әлеуметтік маңызды жобаларына қатысып, жүзеге асыру.

Ізгілікті ортада ұйымдастырылған педагогикалық үдерістің құндылықтары - өздерінің пәндік мазмұнына қарай жеткілікті құндылық және инструментальды құндылықтар типіне бөлінеді. Инструментальды құндылықтар типі қарым-қатынас-құндылықтары, сапа-құндылықтары, білімқұндылықтары және білік-құндылықтар мәнін ашады. Олар болашақ педагогтың аксиологиялық "Мен” кәсіби өсу үдерісінде қалыптасады.

Аксиологиялық “Мен” құндылықтар типологиясы:

1. Кәсіби және әлеуметтік ортада өзінің тұлғалық рөлін бекітумен байланысты құндылық;

2. Қарым-қатынас ортасын кеңейту қажеттілігін қанағаттандырумен байланысты құндылық;

3. Өзін-өзі жеке шығармашылық тұрғыда дамытумен байланысты құндылық;

4. Прагматикалық қажеттіліктерін қанағаттандыруға мүмкіндік беретін құндылық.

Аксиологиялық “Мен” - бұл нақты адам құндылықтары. Аксиологиялық “Мен” жүйелі білім беру ретінде танымдық (білім, білік) ғана емес, сонымен бірге ішкі бағдарда маңызды рөл атқаратын тұлғаға бағытталған эмоционалды-ерікті компоненттерді қамтиды. Педагогикалық үдерістің кәсіби іс-әрекетіндегі ізгілікті құндылықты бағдарына назар аударсақ: Ізгілік құндылықтары субьектінің шығармашылық және белсенді моральды позициясы болып табылады. Болашақ маманның кәсіби шығармашылығы, оның кешенді жалпы қасиеттерін сипаттайтын белсенді, тұлғалық қабілеттер мен мінез-құлық нормаларын жинақтайды. Осы тұста білімқұндылығы және білік-құндылығы болашақ маманның тұлғалық кәсіби-этикалық бағыттылығын құрушы жүйе ретінде жұмыс жасайды. Бұл білімдер оның кәсіби жауапкершілік және кәсіби парызын орындауға мүмкіндік беретін кәсіби құзіреттіліктер негізін құрайды. Құндылықты білімдер тобына гуманитарлық және әлеуметтік экономикалық ғылымдар саласындағы білімдер кіреді (философия, өзін-өзі тану, тарих, педагогика, мәдениеттану), жалпы кәсіби пәндер циклдары бойынша (әлеуметтік-педагогикалық жұмыс теориясы, әлеуметтік-педагогикалық жұмыс тарихы, психология, әлеуметтану, әлеуметтік жұмыстың кәсіби-этикалық негіздері, педагогика, өзін-өзі тану және т.б.). Ерекше құндылықты-білім тобындағы білімдер жинағына маманның жеке адамгершілік қасиеттерін тәжірибеде ашатын “Өзін-өзі тануды оқыту әдістемесі” пәні кіреді. Пәнді оқытудың түпкі негізінде жалпыадамзаттық құндылықтарды саналы түсіну және қабылдау арқылы жүзеге асыру оқу әрекеттері орындалады:

- Гуманистік бағыттылық;

- Жеке және әлеуметтік жауапкершілік;

- Мейірімділік және әділеттілік;

- Адамдар абыройын құрметтеу сезімі;

- Басқаларды түсінуге дайын болу және оларға көмекке келу;

- Эмоционалды тұрақтылық;

- Жеке әлеуметтік бейімделу 
Педагогикалық жүйенің құрамына енетін компоненттердің қызметі ортақ (білім беру, тәрбиелеу, дамыту), яғни бірінші жағдайда - білім беру, екінші жағдайда тәрбиелеу басымдықта. Алайда, тәрбиемен тікелей байланысты білім беру ортасы, адамның санасын қайта жаңарту керек, сонда ғана бүкіл әлем жаңарады, өйткені сана осы әлемнің негізі болып табылады дейді педагог мамандар. Әлемді басқарып тұрған Ақыл-парасат бар, оны біз Жоғары Сана деп қабылдаймыз. Адамзаттың ұлы ойшылдары Жоғары Рухани Бастау бүкіл Әлемді және адамзатты біріктіретінін, әр адамның бойында Жоғары Рухани Бастау - Рух бар деген ұғымға келеді. Рухани бастау жалпыдамзаттық құндылықтар Ақиқат, Сүйіспеншілік, Дұрыс әрекет, Тыныштық, Қиянат жасамау түрінде көрінеді. Осы тұста, “Өзін-өзі тану” пәні адамның үйлесімді дамуын қамтамасыз ететін, әлемнің тұтас, қарастыратын метапән болып табылады. "Өзін-өзі тану” пәнінің метапәндік мазмұны барлық білім беру аймақтарынан өтпелі жол арқылы өтеді. Әр аймақтан нақты түсінік ала отырып, оларды тұтастыққа біріктіріп, толыққанды мазмұн қалыптастырады [9].

Сондықтан да. білім берудің мазмұнына жалпыадамзаттық құндылықтарды мақсатты бағытта енгізу мәселесі қазіргі уақытта “Өзін-өзі тану” рухани-адамгершілік білім беру бағдарламасы аясында айқындалып, көрсетілді деуге толық негіз бар. Ол педагогикалық жүйенің құрамдас бөлігі ретінде аса маңызды формаға ие. Ізгілікті білім беру ортасын құрудың бірқатар педагогикалық мәселелері шешу арқылы, “Өзін-өзі тану” пәнінің мазмұнын тұтас педагогикалық үдеріске интеграциялау барысы міндетті түрде аса мән беруге тиісті жалпыадамзаттық құндылықтар жүйесін анықтайды және аксиологиялық аспектілерін қарастырады [10].

Рухани-адамгершілік білім беру бағдарламасының ең тиімді құндылықтар жүйесінің жіктемесін ғалым Т.И.Петракова ұсынған: 1.Табиғи; 2. Жүре пайда болған; 3. Абсолюттік құндылықтар. Абсолюттік жалпыадамзаттық құндылықтар ол уақытпен өзгермейтін, белгілі бір адамдардың шеңберіне ғана емес, бүкіл адамзат үшін маңызы зор құндылықтар. Жоғарыда айтылғандарға сәйкес, олар “Өзін-өзі тану” рухани адамгершілік білім беру Бағдарламасы үшін маңызды болып саналады. Жалпыадамзаттық абсолюттік құндылықтар - белгілі бір ұлттың, сонымен қатар барлық ұлтқа ортақ құндылықтардың жиынтығы, олар бірін-бірі толықтырып, дамытып отырады және түрлі халықтың діннің, дәуірдің рухани мақсаттарын жақындастыратын туыс ететін құбылыс. Сондықтан да ол жалпыадамзаттық деп аталады [11].

Абсолюттік жалпыадамзаттық құндылықтар адаммен бірге туылған, тумысынан әр адамның жүрегіне салынған, барлық тіршілік өзегінен өткен, барлық адамдар үшін ортақ және уақытпен шектелмейді. Адам ойы сөзі, ісімен ішкі үйлесімділікке жетуі үшін ұстанған жалпыадамзаттық құндылықтар адам тұлғасының: қиянат жасамау - рухани деңгей; ақиқат - интеллектуалдық деңгей; сүйіспеншілік- адамгершілік деңгей; ішкі тыныштық- эмоционалдық деңгей; дұрыс әрекет - физикалық деңгейінде жүзеге асады. Жалпыадамзаттық құндылықтарды жарыққа шығару ізгілікке жол ашады.

Демек, педагогикалық білім беру контесінде “Өзін-өзі тану” ізгілікті ортаны ұйымдастыру үлгісі ретінде алдыңғы орынға шығады. Оған адамға ерекше құндылық деп қарау, ізгілікті бағыттылық, нормалар мен идеалдар тән. Ш.А.Амонашвили “Білім ізгілікке бағытталмаса, адам бойында ізгіліктің нышаны байқалмаса, онда білім пайдасыз ұстаным болып табылады. Яғни керісінше білім беру руханилыққа бет бұрса, онда сөз жоқ өмір бақытқа, тыныштыққа толы болар еді”, - деп ізгілік педагогикасының постулаттарын белгілейді. Демек, рухани-адамгершілік білім баланың ішкі жан дүниесіндегі рухани оқиға екенін ескерсек, Сара Алпысқызының: “Ұстаздың міндеті - шәкірт жүрегін мейлінше лас дүниеден тазалау, аулақ ұстау, мөлдірлік пен ізгілікке толтыру”, - деген пікірі, Ш.А.Амонашвилидің ойымен өзара байланысты үйлесіп жатыр [12].

Қорыта келе: рухани - адамгершілік білім мазмұнының құрамы, құрылымы (ақыл-ой, жүрек, сана) сай компоненттер, білім беру мазмұнының міндеттерін толық кешенді ұйымдастырады. Бұл компоненттер қоғамдағы дағдарыс салдарынан болған өзгерістерге байланысты, тұлғаның әлеуметтік нормаларын, жалпыадамзаттық құндылықтар мен мінезқұлықтарын реттеп отырады. Ғалымдардың педагогикалық идеяларына мән берсек, қоғамды ізгілендіру білім беру мен тәрбиелеу саласының ізгілікті сипатын нығайтуды қажет етеді. Мұның бәрі білім беру ортасын ізгілендірудің негізгі құралы ретінде, құндылықты бағдарын, әлеуетін күшейту, аксиологиялық аспектілерін айқындау мәселесімен тікелей байланысты жүзеге асырылады.

Пайдаланылван ддебиеттер тізімі:

1) Назарбаева С.А. "Самопознание" - возраждение истоковдуховности и нравственных иенностей. // Самопознание (теория, практика, поиск новых парадигм) Выпуск 2, часть 2. Алматы, 2003. - 243 c 
2) Соловьева Г.Г. Философия для детей как модель современного образования // Трансформация системы образования: взгляд философов. - Алматы: - 2016. - 230 с.

3) Зорина Л.Я. Проблемы содержания базового образования и реформа школь // Дидактические проблемы построения базового содержания образования / Под ред. И.Я. Лернера, И.К. Журавлева. - М.: ИТП и МИО, 1993. - С. 22 - 38.

4) Мукажанова Р.А., Омарова Г.А. “Өзін-өзі тану” және басқа оқу пәндері: мазмұны мен әдістерін интеграчиялау мүмкіндіктері. Мұвалімдерге арналган ддістемелік құрал. Алматы. “Бөбек”, ҰҒПББСО, 2013.- 140 б.

5) Ж.Ж.Руссо. Антология гуманной педагогики. Москва. 2010.

6) Қожахметова К.Ж., Таубаева Ш. T. Әлемдік педагогикальқ ой-сана. ХХ васырдың педагогикалық ой-сана антологиясы Алматы, 2011. - 201 с.

7) Амонашвили Ш.А. Как любить детей / Основы гуманной педагогики. В 20 кн. - М.: Амрита, 2012.

8) Амонашвили, Ш.А. В школу - с шести лет /Ш.А. Амонашвили. - М.: Педагогика, 2000. - 180 c.

9) Нысанбаев А.Н., Соловьева Г.Г. Изменимся вместе с детьми: Философское обоснование предмета "Самопознание". - Алмать: МОН РК, 2016. - 61 с.

10) Мукажанова Р.А., Омарова Г.А. “Өзін-өзі тану” рухани-адамгершілік білім беру бавдарламасындавы мұвалімнің рөлі// Оку-әдістемелік құрал.-Алматы, “Бөбек” ҰҒПББСО, 2013.

11) Петракова Т.И. Ценностный потенциал базового образования в духовно-нравственном воспитании учащихся. // Образование: исследовано в мире - M.: OIMRU, 2000.

12) Мукажанова Р.А., Омарова Г.А. “Өзін-өзі тану”- рухани-адамгершілік білім беру багдарламасындагы мұzалімнің рөлі// Оку-ддістемелік құрал.-Алматы, “Бөбек” ҰҒПББСО, 2013. 